\title{
INTERNATIONAL LEGAL REGULATIONS AND ISSUES OF CORRUPT ASSETS RECOVERY
}

\author{
Olena Busol ${ }^{1}$
}

\begin{abstract}
The article is devoted to the issues of international cooperation of the bodies regarding asset recovery and management with a purpose of combating transnational crime. It emphasizes the main provisions of international treaties on combating crime and provides an analysis of foreign legislation in the given sphere. The subject of the study is international legal regulation and problems of corrupt assets recovery, which required the application of interdisciplinary scientific approach in considering its economic, political, philosophical, historical and legal aspects. The purpose of the article is to highlight the main issues that arise when the states try to recover corrupt assets, as well as to provide national governments with appropriate recommendations, taking into account international instruments and best practices. The article considers world practice of conducting criminal proceedings and ex-ecution of court decisions. It covers the features and problems of specialized govern-ment bodies as for the recovery of the assets. The article is based on the application of a set of the following methodologies: philosophical, dialectical and synergetic. The study used the method of systematic analysis, which is the most commonly applied in criminological research to combat corruption. To achieve these purposes, the following research methods are used: analysis of theoretical sources and scientific literature; abstract-logical method in the process of theoretical generalizations and formation of conclusions; prognostic methods. The author applies the comparative method (i.e. the method of comparative jurisprudence) when comparing international documents with the legal norms of other states. Results. Foreign experience shows that development of a modern and effective system of combating organized corruption in any country is possible subject to application of legal norms that meet international standards, as well as the integrated use of advanced computer information technology. The author emphasize the need for OECD (Organization for Economic Co-operation and Development) member states to develop adequate regulations that will allow immediate disclosure and exchange of information on the freeze of assets with foreign jurisdiction, in order to ensure the effectiveness of the asset recovery procedure. Conclusions. It is recommended to adopt laws at the na-tional level or to introduce a regulation in the criminal law of the state on illicit en-richment; to develop comprehensive national strategy; as well as to finance measures to recover corrupt assets within the framework of anti-corruption programs at the state level. It emphasizes the need to have a united state register of assets seized in criminal proceedings. In order to recover assets from abroad, states need to have political will and to use the latest technologies.
\end{abstract}

Key words: corrupt assets, Asset Recovery Offices (ARO), transnational crime, international agreements.

JEL Classification: $010,017,050$

\section{Introduction}

The global spread of modern technologies, such as the Internet, mobile communications, and the international banking system has made national borders more vulnerable. Information technology is widely used by organized criminal groups as a means of preparing and arranging economic crimes. The latest information technologies give members of transnational criminal organizations the opportunity to ensure their anonymity at risk, as well as to involve more people in criminal activities and never be exposed. The largescale withdrawal of funds by corrupt officials from developing countries has created conditions for budget deficits increase, financial imbalances, depletion of international reserves, deepening internal and external imbalances, and growing social stratification in these countries. Corrupt acts and crimes related to abuse of power or official position are usually accompanied by

Corresponding author:

${ }^{1}$ Interagency Scientific and Research Center on

Problems of Combating Organized Crime under

the National Security and Defense Council of Ukraine, Ukraine.

E-mail: lenbusol@gmail.com

ORCID: https://orcid.org/0000-0002-4713-4546 
the withdrawal of acquired funds abroad. The inability or lack of interest of the authorities as for the search of such funds in order to recover them for the benefit of the citizens leads to impunity for corruption.

The specifics of corruption crimes imply the need to transfer the criminal proceeds, which is why such crimes often reach international scales, and the recovery of these funds becomes a matter for several states. Therefore, international cooperation in the recovery of funds received from corruption crimes and withdrawn from the state becomes so much important. World experience in the recovery of assets lost by states as a result of corruption crimes shows that a successful recovery of assets requires compliance with a number of conditions set by the International Center for the Recovery of Assets of the Basel Institute on Governance, 2014.

Following the G20 summit in Hangzhou, People's Republic of China, on September 4-5, 2016, the Heads of States adopted a Communiqué (G20 Leaders' Communiqué, 2016) agreeing, inter alia, to develop a concept aimed at ensuring sustainable balanced growth of the world economy; to increase cooperation in the fight against corruption, as well as to follow the principles of assistance in the search for corrupt officials and assets recovery. It should be noted that over the past four years, some countries, such as Ukraine, have established special bodies to search for and manage assets, but not all of them show high efficiency. Therefore, the topic of the article is high on the agenda in the context of identifying certain issues that prevent some states to achieve real results in the assets recovery that were withdrawn from the states by oligarchs. At the same time, it is important to analyze international documents that regulate cooperation between states and the process of corrupt assets recovery, which are not always effective. The novelty of the study is to identify the reasons for the ineffectiveness of the abovementioned process, and provide recommendations for the application of specific practical measures at both national and international levels.

\section{Legal and practical issues as for recovering corrupt assets in the world}

Criminal-legal issues of illegal enrichment were the subject of research of O. O. Knyzhenko, D. G. Mykhailenko, V. M. Borkov. Such scholars as S. Chernyavsky, V. Nekrasov, A. Titko, L. Gray, K. Hansen, P. Recica-Kirkbride, L. Mills, and others, covered the issues of search for and recovery of corrupt assets in their works. The authors of the article express their sincere gratitude to the scientists and researchers mentioned herein, thanks to whom it became possible to obtain the presented results. However, the problem still has many blind spots. Evidence of this is ongoing criminal proceedings as for the illegal withdrawal of corrupt assets from developing countries, which have been reviewing by the jurisdictions of the United States and European countries for decades already.

Measures aimed at reducing the level of the shadow economy, protecting social infrastructure from criminal encroachment, are applied in most developed EU countries. For example, in 2011, Switzerland passed the act Federal Restitution of Illicit Assets of Politically Exposed Persons Obtained by Unlawful Means, to overcome a number of barriers that had emerged in high-profile cases (e.g., Mobutu, Duvalier). It governs the freezing, forfeiture, and restitution of the assets of politically exposed persons (PEPs) and their close associates in cases where a request for mutual assistance in criminal matters cannot succeed because of the failure of the judicial system in the requesting state. There is no need for a conviction of the PEP in his or her jurisdiction of origin, and the law provides for a presumption of the illicit nature of assets in cases where the enrichment of the PEP is clearly exorbitant and the degree of corruption of the state or the person in question is notoriously great (Larissa Gray, Kjetil Hansen, Pranvera Recica-Kirkbride, Linnea Mills, 2014). Duvalier Law has radically changed the situation with the issuance of corrupt politicians' funds who keep money in Swiss banks (Antikorruptsioner, 2009). According to Duvalier Law, the procedure for issuing money from Switzerland has been significantly simplified. Since then, the account holder, whose money foreign law enforcement agencies require to be issued, must prove the legality of his assets. If the level of corruption in the country of origin of the official is high and the source of his or her income is not established, the Swiss authorities can seize his or her accounts and confiscate the money even without a court decision. The new Duvalier Law was successfully applied in February 2011 against leader and dictator of Libya Muammar Gaddafi incumbent at that time (Butusov, 2011).

There are already glimpses of hope in the world in counteracting corrupt crimes committed by multinational corporations. As an example, one can recall the UK Bribery Act of 2011, as well as the Foreign Corrupt Practices Act of the USA of 1977 (Busol, 2017). This Act applies to all companies located and operating in the United Kingdom of Great Britain. All foreign companies doing business in this country (regardless of their place of official registration) also fall under the application of this Act. Thus, with the entry of the Act into force, British and non-British companies conducting commercial transactions in the United Kingdom that are located in other states will have to demonstrate adequate anti-corruption procedures that meet the requirements of the Act (Bribery Act, 2010).

The experience of states that have dealt with the resonant facts of the withdrawal of assets acquired as a result of abuse of power or commitment of corruption crimes shows that the recovery of such assets is quite 
a difficult task. Thus, the states of the Arab region, which got rid of the dictatorship by holding the socalled Arab Spring, had high expectations as for recovery of funds gained as the corrupt revenues of these regimes. The data in Table 1 illustrate the ratio of withdrawn, frozen and recovered assets in Tunisia, Egypt and Nigeria.

\section{Table 1}

The ratio of withdrawn, frozen and recovered assets of the states of the Arab region

\begin{tabular}{|l|c|c|c|}
\hline $\begin{array}{c}\text { Country and } \\
\text { name of the } \\
\text { former leader }\end{array}$ & $\begin{array}{c}\text { Withdrawn } \\
\text { assets, } \\
\text { billion dollars }\end{array}$ & $\begin{array}{c}\text { Blocked on } \\
\text { accounts in } \\
\text { foreign banks, } \\
\text { billion dollars }\end{array}$ & $\begin{array}{c}\text { Recovered } \\
\text { assets, } \\
\text { billion dollars }\end{array}$ \\
\hline Tunisia, Ben Ali & 5 & 5 & 0.3 \\
\hline $\begin{array}{l}\text { Egypt, } \\
\text { Hosni Mubarak }\end{array}$ & 70 & 1 & 2 \\
\hline $\begin{array}{l}\text { Nigeria, } \\
\text { Sani Abacha }\end{array}$ & 4 & 0.7 & 0.7 \\
\hline
\end{tabular}

A matter of organization of the use of these recovered funds has become quite a challenging issue. Thus, in Nigeria, the funds were returned directly to the state budget of Nigeria. At the same time, some of the supporters of the previous government were still in power. Therefore, the practice of using corrupt assets remained, while non-governmental organizations did not have a significant impact on the distribution of those funds. As a result, many cases of misuse of recovered funds, purchases from the linked companies, and other abuses were reported.

We can recall the experience of recovering assets by formation of non-governmental funds under the control of the international observers. In this way, the assets were recovered in Angola and Peru. However, the disadvantage of such a system is that it deprives the governments of such states of the opportunity to show political will to recover the money (Analytical note, 2019).

\section{Issues of organization of international cooperation of specialized bodies as for recovery and asset management}

The following national agencies of the world community on the assets recovery and management derived from corruption and other crimes, cooperate with the Network of Investigations connected with incomes recovery gained via corrupt or criminal ways, or any other criminal income in general: the Stolen Asset Recovery Initiative (StAR) and the Camden Asset Recovery Inter-Agency Network (CARIN). One can also single out the Asset Recovery Inter-Agency Network for Southern Africa (an informal network of South African police and judicial authorities confiscating proceeds of crime, which acts the same as CARIN); Arab
Anti-Corruption and Integrity Network; The IberoAmerican Network of International Legal Cooperation (Information Exchange Network); the Organization of American States OAS (verifies and communicates with practitioners through a secure computer system); The European Judicial Network (representatives of national judicial and prosecutorial bodies being contact persons for mutual legal assistance); Eurojust (judges and prosecutors from the EU States assisting national authorities in the investigation and prosecution of serious international crimes (Cherniavskyi, Nekrasov, Tytko, 2017).

The Intergovernmental Authority, which is responsible for developing and promoting a strategy to combat money laundering at both the national and international levels, is the Financial Action Task Force (on Money Laundering) (FATF). The FATF is a strategy formation body. The FATF recommendations are aimed, firstly, at improving the legal system in the country, secondly, at increasing the role of financial and credit institutions in combating money laundering, and thirdly, at intensifying international cooperation in this sphere. The FATF operates two types of the lists of countries that evade countermeasures to protect the global financial system from money laundering risks, namely the gray and black lists.

Without active participation in the process of combating money laundering by law enforcement agencies of the states where such a crime has been committed, it is problematic to identify, freeze and confiscate criminal assets. Therefore, law enforcement agencies should respond to illegal actions immediately. In order to analyze any situation quickly and accurately, they should have a very large volume of information about crime both locally and internationally (Harbovskyi, 2006).

In this context, the Egmont Group, an association of 127 Financial Intelligence Units (FIUs) from around the world, has agreed to provide financial intelligence to help each other investigate criminal proceedings. If domestic law allows, the law enforcement agencies of the Egmont Group member state may have recourse to the financial intelligence of another Member State of the Group through its FIU. Available information may include information on bank accounts, questionnaires on the transfer of cash across borders, criminal information and documents stored in public registers.

Relevant state bodies of financial intelligence of foreign countries are the following: The Financial Crimes Enforcement Network (FinCEN) (USA); Financial Transaction and Report Analysis Center of Canada (FINTRAC) (Canada); Zen-tralstelle für Verdachtsanzeigen (Germany); TRACFIN (French Republic); Internal Revenue Service NCIS / ECU (Kingdom of Great Britain), and others. 
Speaking of the organizational structure of such a body as FinCEN, it should be noted that in addition to its full-time employees, the following seconded representatives work in the Office: the representatives of the Customs Service, the Ministry of Finance, the Secret Service, the Federal Bureau of Investigation, the Office for Alcohol, Tobacco and Firearms and Explosives, the Postal Service, the Internal Revenue Service, the Bailiff Service, the Office of Drug Enforcement, and the US Federal Reserve. FinCEN's annual budget is about 300 million USD. The powerful software of artificial intelligence systems AIS FinCEN allows you to automatically scan 60 government and commercial databases and simultaneously analyze disparate information about one object (i.e. organization, individual), located in different US agencies. In addition to processing the financial database, which has had confidential information for almost the last 25 years, FinCEN uses artificial intelligence to prepare reports tentatively titled "Forms as for Criminal Activity". Such forms are drawn up in FinCEN in cases where banks, inspectors of the Ministry of Finance, the tax service and other supervisors find some suspicious transactions in terms of their legality. FinCEN capabilities are now actively used by US law enforcement and intelligence agencies (Nevdashov, 2016).

To further track assets to determine whether an individual or entity or organization has an account with a U.S. financial institution, a foreign jurisdiction may request information from the division of the US Financial Intelligence Unit (FIU) - Financial Crimes Enforcement Network (FinCEN)) - through a procedure known as request 314 (a). Upon receipt of request 314 (a), U.S. financial institutions are required to verify their records and determine whether that institution has opened an account or performed a transaction on behalf of an individual or legal entity or organization that is reasonably suspected by law enforcement, based on reliable information, in involvement in significant money laundering activities. To demonstrate the importance of money laundering, FinCEN requires supporting documents that indicate the following: the decision taken under the case; probable amounts of money withdrawn from the state; country of money origin; type of criminal activity; involvement in a criminal organization and other facts that indicate the importance of the case. The requesting party needs to prove that it cannot obtain relevant information by other traditional methods of investigation and analysis (Derzhavnyi departament SShA, 2012). Only a court that convicts persons accused of committing a criminal act can declare that the money was acquired as a result of criminal activity. Until then, there will be in force a presumption of innocence of a person suspected of embezzlement, money laundering and other financial frauds.

\section{System of international agreements on money laundering, search, seizure and confiscation of proceeds of crime}

Analysis of foreign legislation in this sphere allows us to identify more than 50 bilateral international agreements on combating crime, which, in particular, provide for the transfer of property. Among them there are the European Convention on the Extradition (European Convention, 1957) and its Additional Protocols (Protocol, 1975) and (Protocol, 1978); the European Convention on Mutual Assistance in Criminal Matters (European Convention, 1959) and its Additional Protocol (Protocol, 1978); European Convention on the Supervision of Conditionally Sentenced or Conditionally Released Offenders (European Convention, 1964); European Convention on the Transfer of Proceedings in Criminal Matters, 1972; Convention on the Transfer of Sentenced Persons (Convention, 1983). The recovery of the assets, which have been obtained criminally, to the state is a fundamental principle of the United Nations Convention against Corruption (United Nations Convention, 2003).

The legislation of developed foreign states stipulates that international search, seizure and confiscation of criminally obtained money and property is an act of inter-national legal assistance carried out in accordance with agreements concluded or adopted on the basis of instructions of competent law enforcement agencies or courts of foreign states by identifying and ensuring the safety of confiscated money, valuables and property obtained by criminal means belonging to the accused, as well as proceeds of crime, their transfer to another state for use in criminal proceedings evidence or for damages compensation (Harbovskyi, 2006).

The Convention on Laundering, Search, Seizure and Confiscation of the Proceeds from Crime (Convention, 1990) is an international legal instrument aimed at pursuing a common criminal policy against serious crimes. The Article 13 of the Convention stipulates that a Party, which has received a request for confiscation of funds or proceeds situated in its territory, shall enforce a decision of the court of the requesting Party to confiscate such funds or proceeds or forward the request to its competent authorities for a decision on confiscation, and in case of receipt of such resolution, shall execute it. Pursuant to the Article 15, the requested Party shall dispose of any confiscated property in accordance with its domestic law, unless the parties concerned agree otherwise.

International instruments for counteracting crimes are also such documents as the General Assembly Resolution 217, according to which everyone has the right to an effective remedy by the competent national tribunals for acts violating the fundamental rights granted to him or her by the constitution or by law 
including the protection of the right to own property both individually and together with others; The Declaration of Basic Principles of Justice for Victims of Crime and Abuse of Power dated November 23, 1985, approved by UN General Assembly resolution №40/34 (Declaration, 1985), which defines what is meant by victims of crime; the rights of victims of crime; the rights of offenders and third parties; The UN Standard Minimum Rules for Non-Prison Measures (Tokyo Rules) adopted by UN General Assembly Resolution 45/110 (1990).

UN General Assembly Resolution 45/107 (Resolution, 1990) contains recommendations on international cooperation in crime prevention and criminal justice in the context of development and the new international economic order, which empha-size the adoption of necessary legislative and other measures in order to provide vic-tims of crime with effective means of legal influence.

The Article 13 of the Model Treaty on Extradition, adopted on December 14, 1990 by UN General Assembly Resolution 45/116 (Resolution 1990), stipulates that all property found in the requested State which has been acquired as a result of a crime or which may be required as evidence, shall be transferred, at the request of the requested State, if extradition permits so.

According to paragraph $2 \mathrm{~d}$ of the Article 1 of the Model Treaty on Mutual Assistance in Criminal Matters of UN General Assembly Resolution 45/117 (Resolution, 1990), mutual legal assistance should be provided in the search and seizure of property. The Article 17 of the same document recommends that law enforcement authorities, within the limits permitted by national law, shall comply with requests for the search, confiscation and transfer to the requesting State of any material for use as evidence, subject to the rights of bona fide third parties. The given Resolution also adopted the Optional Protocol to the Model Agreement on Mutual Legal Assistance in Criminal Matters, which deals with proceeds of crime. The proceeds of crime in paragraph 1 means the property obtained or sold, directly or indirectly, as a result of the offense, or other benefits derived from the offense. Paragraph 2 sets out the procedure for implementing the requested party's requests for the establishment and tracing of such proceeds, according to which the requested state needs to take measures to establish whether the proceeds of the offense are within its jurisdiction. Paragraph 4 stipulates the measures permitted by its legislation in order to prevent any transactions, transfer or use of these revenues until the court of the requested state makes a final decision.

At the International Conference on Preventing and Controlling Money-Laundering and the Use of the Proceeds of Crime, held under the auspices of the United Nations, June 18-20, 1994 in Courmayeur, Italy
(UN Document E, 1994) such measures as confiscation sanctions and the disclosure in course of investigation were listed as the most effective in preventing economic crimes. Prior to its widespread introduction into practice, it is recommended to expand the practice of confiscation of assets and the possibility of using such temporary measures as freezing or seizure of assets, which should also be allowed as for proceeds from crimes committed abroad.

According to the World Conference on Organized Transnational Crime, held at ministerial level on November 21-23, 1994 in Naples, Italy, crimes committed for economic gain can be successfully combated through the confiscation of proceeds or any other property of the involved individuals and organizations. In some legal systems, high importance is attached to the blocking, seizure and confiscation of assets related to illegal activities ...; it is necessary that the procedures related to freezing, seizure and confiscation have a wide scope and allow the confiscation of a large number of property of offenders, in order to deprive them of all proceeds of crime; taking into account the existing legal norms and practice of counteracting organized crime, it is expedient to confiscate any property acquired as a result of organized criminal activity and any acquired assets (Report, 1994).

The analysis of international agreements on money laundering, search, seizure and confiscation of proceeds of crime shows a complex, however, well ordered system that can effectively combat corruption and organized crime in this sphere. According to the point of view of author of the article, the effective application of international treaties in practice in some developing countries is hampered by the peculiarities of national legislation and "crisis-type" crime. In such states, corruption is not just an isolated phenomenon, but an organic consequence (and symptom) of the fundamental social crisis in the state, which is the subject of a separate scientific study.

\section{Effectiveness of criminal proceedings and issues of execution of court deci-sions}

Taking into account the international agreements concluded by Ukraine, when searching for money and property obtained by criminal means, as well as their arrest and collection of related evidence, all types of procedural actions provided by the criminal procedure legislation of Ukraine, including seizure and search, may be used. Confiscation is carried out on the basis of a court judgment or other court decision and exclusively within the procedures in accordance with the law of the state in the territory of which the property is located. In this case, the party, which confiscated the proceeds or property, shall dispose them in accordance with its national law and administrative procedures. 
World practice knows three ways to enforce a foreign court decision. The first method involves the need for a procedure for recognition of a foreign decision, i.e. the so-called "issuance of an exequatur" (French Republic). The second approach involves the need to register the decision of a foreign court in a special register (Kingdom of Great Britain). The third method involves checking the correctness of the decision only from a formal point of view and its verification of compliance with the public order of the state of the court (Germany, Italy, Belarus). This method allows the possibility of refusing to recognize the decision of a foreign court. For example, according to the legislation of the Republic of Belarus, a foreign court decision may not be enforced if it contradicts the sovereignty of the state, threatens its security or contradicts the basic principles of its legislation. In fact, the same grounds are stipulated in paragraph 328 of the Civil Procedure Code of Germany. However, the last of these grounds sounds a bit broader, i.e. if "the recognition and enforcement of a foreign judgment may lead to a violation of the basic principles of public order and the protected rights of individuals in the executing country" (Huban, 2015).

It should be noted that during the recovery of assets obtained as a result of acts of corruption, certain political issues may arise. The states, to which the assets were withdrawn, may be concerned about the possibility of rediversion of assets due to the persistence or resumption of corruption in the requesting state, especially when the official is still in office or has a significant power. Also, the requesting state may resist the efforts of the state, to which the assets were transferred, to dictate the terms of use of the confiscated property. In such cases, in order to facilitate the recovery of assets and their monitoring, international organizations and civil society organizations are being involved (Tykhonova, 2017).

The criminal law of some states does not take into account international norms, which introduces some ambiguity into the issue of adaptability of national legislation. In some countries, the object of confiscation is defined as funds or other property (for example, in Ukraine), but property rights are not taken into account, which excludes from the confiscation of the right to claim certain objects. Similarly, conditions, under which property is no longer considered to be derived from a crime, may not be envisaged. As a result, certain assets, in particular interest on deposits with foreign banks, will not be subject to confiscation under national law. Among the difficulties that arise at the final stage there are the following: the delay of court proceedings by the defendant through the filing of complaints and appeals against court decisions; lack of possibility to obtain evidence due to failure to establish the location of witnesses (Analytical note, 2019).

\section{The reasons for inefficiency and conditions for the effective functioning of specialized state bodies for assets recovery}

With regard to the management of seized property, in some states, appropriate specialized bodies have been established (for example, the English SOCA, the Czech UOKFK, the French AGRASC, and others; and sometimes it is done by units within ordinary bodies (US Marshals Service within the Department of Justice).

\section{Application 1. Asset Recovery Offices (ARO) ${ }^{1}$}

Austria designated the Federal Criminal Police (Bundeskriminalamt - Referat "Vermögensabhöpfung").

Belgium designated L'Organe Central pour la Saisie et la Confiscation (Central Office for Seizure and Confiscation - COSC), established by the law of 26 March 2003.

Bulgaria designated two AROs, the Commission for Establishing Property from Criminal Activity (CEPACA, which subsequently changed its name to CEPAIA), and the Supreme Prosecutor's office.

Cyprus designated the Unit for Combating Money Laundering (MOKAS-FIU Cyprus).

The Czech Republic designated the Unit Combating Corruption and Financial Crimes (UOKFK), International Cooperation Department, and enacted Act no. 273/2008.

Denmark designated the State Prosecutor for Serious Economic Crime (Statsadvokaten for Særlig Økonomisk Kriminalitet)

Estonia designated the V Division, Investigation Department, Central Criminal Police

Finland designated the National Bureau of Investigation, Criminal Intelligence Division/Communications Centre France designated the Central Directorate for Criminal Investigations (Plateforme d'Identification des Avoirs Criminels - PIAC).

France recently designated another ARO, the Agency for the management and recovery of the assets seized and confiscated (AGRASC). The notification to the Commission is under way.

Germany designated two AROs, the Federal Criminal Police (Bundeskriminalamt Referat SO 35 "Vermögensabschöpfung") and the Ministry of Justice (Bundesamt für Justiz).

Greece designated the Financial and Economic Crime Unit within the Ministry of Finance, according to law no. 3842/2010.

Hungary designated the National Investigation Office (Nemzeti Nyomozó Iroda).

Ireland designated the Criminal Assets Bureau, established by the Criminal Assets Bureau Act of 2005.

Latvia designated the Economic Police Department of the Central Criminal Police Department of the State Police.

Lithuania designated two AROs, the Criminal Police (Lietuvos kriminalines policijos biuras) and the General Prosecutor Office (Lietuvos Respublikos generaline prokuratura) Luxembourg designated the Parquet du Tribunal d'Arrondissement de Luxembourg, Section éco-fin.

${ }^{1}$ Report (2011). 
Vol. 6, No. 4, 2020

TheNetherlands designated the CriminalAssets Deprivation Bureau PublicProsecution Service (Bureau Ontnemingswetgeving Openbaar Ministerie - BOOM).

Poland designated the Assets Recovery Unit, Criminal Bureau, General Headquarters of Police.

Slovakia designated the Financial Intelligence Unit of the Bureau of Combating Organised Crime of the Presidium of the Police Force.

Spain designated two AROs: the Intelligence Centre against Organised Crime (CICO) and the Anti-drugs Special Prosecution Office (Fiscalia Especial Antidrogas) at the Ministry Of Justice.

Sweden designated two AROs: the National Criminal Intelligence Police Service and the National Economic Crimes Bureau (Ekobrottsmyndigheten).

The United Kingdom designated two AROs: the Serious Organised Crime Agency (SOCA) for England, Wales and Northern Ireland and the Scottish Crime and Drug Enforcement Agency (SCDEA) for Scotland.

The remaining Member States provided the following information on their progress towards designation of an ARO:

Malta indicated that the National Fraud Squad will be designated as the National ARO.

Portugal indicated that a group appointed under the authority of the Minister of Justice has been given the task of establishing the structure of the future ARO.

Romania indicated that an ARO would be established under the responsibility of the Ministry of Justice. The ARO would be multidisciplinary and involve the law enforcement structures that have temporarily acted as the ARO. The relevant personnel, including the CARIN contact point, would be detached to the future ARO.

Slovenia indicated that consideration is being given to establishing an ARO under the responsibility of the Public Prosecution Office.

Italy indicated that consideration is being given to establishing an ARO under the responsibility of the Ministry of Interior. The relevant provisions for internal designation are being drafted.

In some countries, such as Ukraine, where corrupt practices are widespread, the biggest problem today is not about finding the corrupt assets but about recovering them, that is, passing a reasonable court verdict in criminal proceedings. Moreover, if the recovery is planned to be carried out abroad, it is necessary that the verdict is also recognized by the European court at the place of recovery. So far, reports on seizure of accounts abroad are much more common than reports on requests for seizure of the accounts. In addition, the seizure of assets abroad requires a reasonable request from the Ukrainian investigative body, and what is more important - it should be made in accordance with the European standards, not Ukrainian ones (Shemelin, 2015).

Indeed, the EU clearly adheres to the presumption of innocence, so the investigator should act very carefully when preparing the relevant evidence before the European Court. The property owner usually files a lawsuit to lift the seizure of his or her assets, which can result in the EU deciding to pay large compensation to the state that made the mistake. Much depends on whether legislators or local officials understand that if criminal proceedings are instituted against a bank beneficiary in Ukraine and an attempt is made to recognize the case abroad, in the country where it is located, it may not always be very effective. The fact is that the European courts are full of criminal cases and the proceedings against the Ukrainian offender who withdrew the money can be quite long. For example, a Liechtenstein's court, in agreement with the local prosecutor's office, unblocked 13 million Swiss francs on the accounts of a well-known Ukrainian judge because the Ukrainian prosecutor's office failed to provide evidence that the money was illegal (Likhachov, 2018). The situation is complicated also by the fact that Ukraine has not yet acceded to the international convention on ensuring Ukraine's access to non-residents' accounts, has not signed or ratified the relevant agreement, which will provide access to Ukrainian residents' accounts in foreign banks. And this happens when 101 states and almost all offshore jurisdictions have already signed the relevant convention, which allows the tax authorities of the signatory states to automatically obtain information from the relevant authorities of other states. Along with a large number of banking institutions, there is no unified register of bank accounts in Ukraine, which would make it possible to obtain this information promptly until the money are gone in the event of an investigation. However, today such registers have been established and are successfully operating in Lithuania, France and Germany. In Ukraine, the problem of interdepartmental cooperation is acute, since upon receiving requests from law enforcement agencies from other government agencies information is not provided immediately, as it should be. In addition, it should be noted that there are difficulties in internal cooperation between government agencies, as well as the lack of effective mechanisms for cooperation to combat corruption. The activities of interdepartmental working groups on asset recovery are usually complicated by the poor coordination of the various agencies involved in anti-corruption activities.

In the context of the study, it is worth mentioning the forensic audit service which is in demand by large and medium-sized organizations in developed countries that helps to expose thieves-managers, as well as search for money stolen by ex-managers. At the same time, all internal accounting is checked and the company's transaction links are built. As a result, it becomes possible to establish the companies to which funds are transferred by a certain person. The process of providing this ser-vice involves quite a large number 
of staff, namely accountants, detectives, lawyers and economists. It is used in cases where huge amount of money is involved. A forensic auditor should be able not only to find inaccuracies and intentionally formulated errors in transactions, but also to understand the true purpose of the economic transaction. The search is carried out on a computer, in special software, which records and displays a step-by-step scheme of the crime: where the credited money went, to which offshore, where the money goes later to, who stole the money, who currently disposes of it, etc.

There is a cross-border search for the recovery of money from abroad, which, in addition to forensic audits, also includes the work of detectives and economic intelligence. If private detectives found out that the suspicions are serious, they, together with a team of lawyers involved in the cross-border search for assets, apply to the pretrial investigation authorities and to the court with claims, requesting information from certain registers.

When public authorities try to start this process on their own, they are already sending a signal to the other party that something is already happening. And if the special authorities fail to achieve the result, then, of course, they can hire a private company to search for assets, but time will be lost, the assets might be transferred somewhere, which will make it much more difficult to find them afterwards. Assets recovery is a process where each subsequent stage depends much on whether the previous one was carried out properly. Limited operational data complicates or even makes it impossible to conduct a successful investigation. That is, the better the implementation of the previous stages, the better the chances of success. The complexity of asset recovery processes and the lack of technical knowledge of the professionals in developing countries are major obstacles to a successful asset recovery process. It needs, first of all, the possibility of the successful search of the assets. When searching for assets, the investigator determines the ways of obtaining them and identifies the location of criminal proceeds (Cherniavskyi, Nekrasov, Tytko, 2017).

In the context of addressing this issue, the World Bank has made the following recommendations: developed and developing countries should maintain comprehensive statistics on asset recovery cases, including assets frozen or confiscated, repara-tions or restitution ordered, and assets recovered. Gaps in the data should be identified and their collection addressed. Where possible, countries should gather data on the various means to recover assets, including criminal and non-conviction based confiscation, administrative confiscation, private civil actions, or other forms of direct recovery. Statistics on cases and information on laws and results should be publicly available and accessible at a central location such as a website (Larissa Gray, Kjetil Hansen, Pranvera Recica-Kirkbride, Linnea Mills, 2014).
For example, in order to partially implement this recommendation, in 2020, the President of Ukraine V. Zelenskyi submitted to the Verkhovna Rada of Ukraine a bill on "civil confiscation of corrupt assets of officials", which also provides for the return of criminal liability for illicit enrichment. According to the norms of the bill submitted for consideration, confiscation of illegal assets by court decisions is envisaged in a civil procedure without a conviction. Illegal enrichment will be prosecuted if the subject of illicit enrichment is assets in excess of significant amounts, as defined in the United Nations Convention against Corruption (United Nations Convention, 2003). Currently, anticorruption bodies in Ukraine deal only with the most significant corruption threats. Cases involving less than 380,000 EUR but more than 30,000 EUR are dealt with in civil proceedings by recovering unjustified assets to the state revenue. The bill on illegal assets of officials will allow the state to confiscate these assets even under the previously opened cases.

Experts confirm that aid disbursements to the most aid-dependent countries co-incide with significant increases in deposits held in offshore financial centers known for bank secrecy and private wealth management. Aid capture by ruling politicians, bureaucrats and their cronies is consistent with the totality of observed patterns: it can explain why aid does not trigger flows to non-havens, why the capital outflows occur precisely in the same quarter as the aid inflows and why the estimated effects are larger for more corrupt countries. Other explanations are possible but we find them harder to reconcile with all the patterns in the data. It cannot be ruled out that firms benefiting from aidsponsored spending receive payments in quarters with aid disbursements and deposit the funds with foreign banks; however, this mechanism cannot explain why the money only flows to havens. It seems even less likely that the results reflect profit shifting by multinational firms, the effect of aid on income through aggregate demand and portfolio adjustments by commercial and central banks. World Bank estimates suggest a leakage rate of around $7.5 \%$ for the average highly aiddependent country (Jorgen Juel Andersen, Niels Johannesen, Bob Rijkers, 2020).

The positive influence of political will is demonstrated by Indonesia, the gov-ernment of which after the fall of the Sukarno regime (President of Indonesia in 1945-1967) embodied in the laws on combating legalization (laundering) of criminal proceeds the best world experience and introduced the codification of court cases to prevent the impact on lawsuits for the recovery of assets withdrawn by Sukarno and the persons from among the supporters of this political leader. On the whole, the codification of court cases has had a positive impact on the work of the Indonesian judiciary in general and in anti-corruption cases in particular (Analytical note, 2019). 


\section{Summary and conclusions}

The purpose of recovery of the withdrawn funds from the state, on the one hand, is to promote the stabilization of the domestic economy, and on the other - to set a precedent that demonstrates the inevitability of punishment for corruption crimes as for high-ranking officials.

Our study shows that:

1) The formation of a modern and effective system for combating organized corruption in any country is possible subject to the application of regulations that meet international standards and the integrated use of advanced computer information technology.

2) It is necessary to support the opinion that countries should engage in a do-mestic or international policy debate on how asset returns can be incorporated into settlement agreements in corruption cases and should consider legislative changes necessary to permit the inclusion of third parties in settlement agreements in foreign bribery cases ${ }^{2}$.

3) In order for the asset recovery procedure to be effective, OECD member countries (Organisation for Economic Co-operation and Development, OECD) need to develop adequate regulations that will allow for the immediate disclosure of information and the exchange of information on freezing of accounts by a foreign jurisdiction.

4) The adoption of laws or the introduction of a rule in the criminal law of the state on illicit enrichment will help to overcome the existing barriers in recovery of assets.

5) All countries of the world should have a comprehensive national strategy and to finance at the state level the measures to recover corrupt assets within the framework of anti-corruption programs; the united state register of assets seized in criminal proceedings.

6) To recover assets from abroad, states need to have political will, to use the latest technologies and modern equipment. Among media representatives and experts investigating and commenting on the economic crimes of the oligarchic regime, the prevailing opinion is that if stolen property and assets are recovered from abroad, such states as Ukraine, for example, practically would not need international financial assistance. However, the recovery of assets is a long process, for example, the case of former Prime Minister of Ukraine P. Lazarenko regarding stolen assets, is considered by US courts for more than 10 years already. Ukraine is now claiming a refund to the budget of 160 million USD from the former prime minister's money that he has withdrawn from the country. Therefore, the efforts of relevant international organizations should be aimed at developing a mechanism and facilitating the acceleration of such proceedings.

7) There is a need for scientists to clarify the mechanism underlying the direct correlation between the payment of international aid to a particular state and the accumulation of assets on the offshore accounts of the economic elite of this state.

\section{References:}

Capacity Building in Asset Recovery. Available at: http://www.baselgovernance.org/fileadmin/docs/publications/ books/Capaci... (accessed 29 September 2020).

Shveitsariia ta hroshovi dyktatury [Switzerland and monetary dictatorships]. Available at: http://www.rts.ch/ info/suisse/2906645-gel-d-avoirs-la-suisse-a-restitue-1-7-milliard-en-15-ans.html (accessed 15 November 2019). Pershocherhovi zakhody pobudovy systemy povernennia v Ukrainu aktyviv, nabutykh zlochynnym shliakhom [Priority measures to build a system for returning criminally acquired assets to Ukraine] (2019). Analitychna zapyska. Natsionalnyi instytut stratehichnykh doslidzhen. Available at: http://old2.niss.gov.ua/articles/1634/ (accessed 29 September 2020).

G20 Leaders' Communiqué (2016). Hangzhou Summit, Hangzhou, Sept. 5. Available at: http://www.g20.utoronto.ca/2016/160905-communique.html (accessed 30 September 2020).

Larissa Gray, Kjetil Hansen, Pranvera Recica-Kirkbride, Linnea Mills (2014). Few and Far: The Hard Facts on Stolen Asset Recovery. International Bank for Reconstruction and Development / The World Bank and the OECD. Available at: https://www.oecd.org/dac/accountable-effective-institutions/Hard\%20Facts\%20Stolen\%20Asset\% 20Recovery.pdf (accessed 30 March 2020).

Shveitsariya. Antikorruptsioner [Switzerland. Anti-corruption]. Available at: http://www.anti-corrupcioner.ru/ node/ 106 (accessed 11 March 2020).

Butusov, Yu. (2011). «Zakon Diuvalie»: mysholovka dlia sanovnykh koruptsioneriv [Duvalier's Law: a mousetrap for dignitaries]. Dzerkalo tyzhnia. 25 liut. № 7. Available at: http://www.dt.ua/newspaper/articles/76314 (accessed 24 April 2020).

Cherniei, V. V., Husariev, S. D., Cherniavskyi, S. S. et al. (2018). Realizatsiia derzhavnoi antykoruptsiinoi polityky v mizhnarodnomu vymiri: materialy III Mizhnar. nauk.-prakt. konf. (Kyiv, 7 hrud.). Kyiv. (in Ukrainian)

Bribery Act (2010). URL: Ministry of Justice. Available at: http://www.justice.gov.uk/publications/bribery-bill.htm/ (accessed 24 February 2020).

\footnotetext{
${ }^{2}$ Jørgen Juel, Andersen Niels, Johannesen Bob Rijkers, 2020. Policy Research Working Paper 9150. Elite Capture of Foreign Aid. Evidence from Offshore Bank Accounts. World Bank Group. URL: http://documents.worldbank.org/curated/en/493201582052636710/pdf/Elite-Capture-of-Foreign-Aid-Evidence-from-Offshore-Bank-Accounts.pdf?fbclid=IwAR2TtyFxsgqkW1DzkhSGjTwozt0YKTjKk-LL98ac6Y_drJ8z6mt6IjUDYQE.
} 
Cherniavskyi, S. S., Nekrasov, V. A., Tytko, A. V. et al. (2017). Tinova ekonomika v Ukraini: stan, tendentsii, shliakhy podolannia: analit. ohliad [Shadow economy in Ukraine: state, tendencies, ways of overcoming]. Kyiv. (in Ukrainian)

Harbovskyi, L. A. (2006). Zabezpechennia konfiskatsii hroshovykh sum i maina, otrymanykh zlochynnym shliakhom (mizhnarodno-pravovi aspekty) [Ensuring confiscation of money and property obtained by criminal means (international legal aspects)]. Naukovyi visnyk Natsionalnoho universytetu DPS Ukrainy, vol. 3(35), pp. 248-255. (in Ukrainian)

Nevdashov, I. FinCEN - amerikanskii otvet finansovym prestupleniyam. Ekonomicheskii terrorizm. Available at: http://www.e-terror.ru/it2b2.view7.page18.html (accessed 24 December 2019).

Mekhanizmy ta protsedury povernennia aktyviv u SShA: praktychnyi posibnyk dlia mizhnarodnoi spivpratsi. Derzhavnyi departament SShA. Available at: http://star.worldbank.org/star/sites/star/files/asset_recover_ tools and procedures - us guide ukrainian.pdf (accessed 22 June 2020).

European Convention on Extradition (1957). ETS. № 024. Paris. 13 Des. Available at: https://www.coe.int/en/ web/conventions/full-list/-/conventions/treaty/024 (accessed 01 June 2020).

Additional Protocol to the European Convention on Extradition (1975). ETS № 086. Strasbourg. 15 Oct. Available at: https://www.coe.int/en/web/conventions/full-list/-/conventions/treaty/086 (accessed 01 June 2020).

Second Additional Protocol to the European Convention on Extradition (1978). ETS № 098. Strasbourg. 17 Mar. Available at: https://www.coe.int/en/web/conventions/full-list/-/conventions/treaty/098 (accessed 02 June 2020).

European Convention on Mutual Assistance in Criminal Matters (1959). Strasbourg, ETS № 030. 20 Apr. Available at: https://www.coe.int/en/web/conventions/full-list/-/conventions/treaty/030 (accessed 02 June 2020).

Second Additional Protocol to the European Convention on Extradition (1978). ETS No.098. Strasbourg. 17 Mar. Available at: https://www.coe.int/en/web/conventions/full-list/-/conventions/treaty/098 (accessed 02 June 2020). European Convention on the Supervision of Conditionally Sentenced or Conditionally Released Offenders (1964). ETS № 051. Strasbourg, 30 Nov. Available at: https://www.coe.int/en/web/conventions/full-list/-/conventions/ treaty/051 (accessed 08 June 2020).

European Convention on the Transfer of Proceedings in Criminal Matters (1972). ETS № 073. Strasbourg, 15 May. Available at: https://www.coe.int/en/web/conventions/full-list/-/conventions/treaty/073 (accessed 08 June 2020).

Convention on the Transfer of Sentenced Persons. European Treaty Series-No (1983). ETS № 112. Strasbourg. 21 Mar. Available at: https://rm.coe.int/1680079529 (accessed 08 June 2020).

United Nations Convention against Corruption (2003). General Assembly resolution № 58/4. 31 Oct. Available at: https://www.unodc.org/documents/brussels/UN_Convention_Against_Corruption.pdf (accessed 03 June 2020).

Convention on Laundering, Search, Seizure and Confiscation of the Proceeds from Crime (1990). ETS No. 141. Strasbourg. 08 Nov. Available at: https://www.coe.int/en/web/conventions/full-list/-/conventions/treaty/141 (accessed 01 June 2020).

United Nations General Assembly (1948). General Assembly resolution 217. Paris. 10 Dec. Available at: https://www.un.org/en/universal-declaration-human-rights/ (accessed 03 June 2020).

Declaration of Basic Principles of Justice for Victims of Crime and Abuse of Power (1985). Adopted by General Assembly resolution № 40/34. 29 Nov. Available at: https://www.un.org/en/genocideprevention/documents/ atrocity-crimes/Doc.29_declaration\%20victims\%20crime\%20and\%20abuse\%20of\%20power.pdf (accessed 11 June 2020).

United Nations Standard Minimum Rules for Non-custodial Measures (The Tokyo Rules) (1990). Adopted by General Assembly resolution № 45/110. 14 Dec. Available at: https://www.ohchr.org/Documents/ ProfessionalInterest/tokyorules.pdf (accessed 22 May 2020).

International co-operation for crime prevention and criminal justice in the context of development (1990). Resolution / adopted by the General Assembly. A/RES/45/107. Des. 14. Available at: https://www.unodc.org/ pdf/model_treaty_extradition.pdf(accessed 22 May 2020).

Model Treaty on Extradition (1990). Adopted by General Assembly resolution № 45/116, subsequently amended by General Assembly resolution 52/88). 14 Des. Available at: https://www.unodc.org/pdf/model_treaty_ extradition.pdf (accessed 20 May 2020).

Model Treaty on Mutual Assistance in Criminal Matters (1990). Adopted by General Assembly resolution № 45/117, subsequently amended by General Assembly resolution № 53/112. 14 Des. Available at: https://www.unodc.org/pdf/model_treaty_mutual_assistance_criminal_matters.pdf (accessed 22 May 2020).

UN Document E / CONF. 88/7. July 12. 1994, pp. 5-8.

Report of the World Ministerial Conference on Organized Transnational Crime (1994). A/49/748. Dec. 2. Available at: https://www.imolin.org/imolin/naples.html?print=yes (accessed 16 May 2020).

Huban, V. (2015). Problemy vyznannia ta vykonannia rishen inozemnykh sudiv v Ukrainy [Problems of recognition and execution of decisions of foreign courts in Ukraine]. Yurydychna Hazeta online. 06 zhovt. Available at: http://yur-gazeta.com/publications/practice/vikonavche-provadzhennya/problemi-viznannya-ta-vikonannyarishen-inozemnih-sudiv-v-ukrayini.html (accessed 30 May 2020). 
Tykhonova, O. V. (2017). Zasady mizhnarodnoho spivrobitnytstva shchodo povernennia aktyviv, oderzhanykh koruptsiinym shliakhom [Principles of international cooperation on the return of assets obtained through corruption]. Kryminalno-pravovi ta kryminolohichni zasady protydii koruptsii: zb. tez dop. V Mizhnar. nauk.prakt. konf. (31 berez. 2017 r., Kharkiv, Ukraina). Kharkiv: KhNUVS. (in Ukrainian)

Shemelin, D. (2015). Shvydshe za vse, stosovno stiahnennia zarubizhnykh aktyviv stvorennia Ahentstva ne pryvede ni do yakykh realnykh zmin [Most likely, the creation of the Agency will not lead to any real changes in the recovery of foreign assets]. Available at: http://attorneys.ua/uk/publications/ (accessed 29 September 2020).

Likhachov, M. Suchasni mozhlyvosti transkordonnoho rozshuku aktyviv vrazhaiut [The current capabilities of cross-border asset search are impressive]. Available at: http://www.sklaw.com.ua/ukr/news/366 mikola lihachov_suchasni_mozhlivosti_transkordonnogo_rozshuku_aktiviv.html (accessed 29 September 2020).

Report from the Commission to the European Parliament and to the Council. Brussels (2011). Available at: http://ec.europa.eu/home-affairs/news/intro/docs/1_EN_ACT_part1_v8.pdf (accessed 05 August 2020). 